\title{
N Macrothink

\section{Relationship between Job Satisfaction and HR Practices, an Empirical Research of Different Sectors of University Teachers in Pakistan}

\author{
Imran Khan \\ Department of Management Sciences, The Islamia University of Bahawalpur, \\ Bahawalnagar Campus. \\ E-mail: Imrankhan_lec@yahoo.com
}

\begin{abstract}
Tauqir Ahmad Ghauri
Department of Management Sciences, The Islamia University of Bahawalpur, Bahawalnagar Campus

E-mail: Tauqir.ahmad@iub.edu.pk
\end{abstract}

Kashif Akram

Department of Commerce, The Islamia University of Bahawalpur, Bahawalnagar Campus

E-mail: kashifdms@yahoo.com

Accepted: March 25, $2012 \quad$ Published: May 02, 2012

Doi:10.5296/ijld.v2i3.1756 URL: http://dx.doi.org/10.5296/ijld.v2i3.1756

\begin{abstract}
A number of researchers focus on the issue of HR practices and their impact on performance of employees particularly on developed countries. Few researches are there for the implication of these practices in developing countries. The current research focus on relationship between job satisfaction of university employees and focus HR practices which are compensation, promotion, empowerment and performance evaluation practice. It also focus on demographic attributes impact on job satisfaction and HR practices. Result shows that male university teachers are more satisfied with their job but female teachers are more
\end{abstract}


satisfied with HR practices of universities. Public sector university teachers are more satisfied and found direct relationship in length of experience and job satisfaction. HR practices have positive correlation with job satisfaction. Pakistani universities have to improve the current level of HR practices, specially compensation practice for lucidity of their teacher's career.

Keywords: HR Practices; Job Satisfaction; University Teachers; Under Develop Countries; Pakistan.

\section{Introduction}

Many researches show the positive link with the performance of employees and organization. All these researches are in consideration of developed countries. Little researches are there on developing countries like Pakistan. Level of education in Pakistan is low because of performance of university teachers. There is not a single university of Pakistan which is ranked among top universities of world. Current study is focusing on the performance of different sectors of university teachers of Pakistan and a forward step to work on determinant of their performance. The objective of the study is to provide the guideline to the different sectors of Pakistani Universities to improve the performance of their teaching staff which directly impact on the learning of students by utilizing different HR techniques.

\section{Literature Review}

\subsection{Job Satisfaction}

Research about job satisfaction focus on some factors that are considered to relate with satisfaction or dissatisfaction in the work environment and it examines the effect of human resource practices on job satisfaction. Studying the factor that affect job satisfaction the literature of current study referred to those factors that are very close to teacher turnover in universities that shows that dissatisfied teachers more likely to switch from there institutions (Hodson, 1989). This is also studied from previous research in other disciplined like management, Marketing and in organizational behavior shown that HR practices are primary indicator of job satisfaction to the work (Mottaz, 1985). In addition some time job satisfaction use as intervening variable (Singhal \& Srivastva, 1982).

Particularly HR practices are more important component of work condition that influence the job satisfaction of teacher (Ssesanga \& Garrett, 2005). With respect of HR practices in clearly explained about the behavior of top management that is supportive and encouraging in universities about rules, teacher learning, instructional practices, recognition and reward for good work and equal distribution of work load (Michalos, 1980). There is highly relationship between HR practices and teacher's perception in universities culture (Luna-Arocas \& Tang, 2004). In addition the behavior of students at school like learning behavior and student's interfering during lecture are also related to satisfaction (Schmidt, 2007). Previous research also studied about relationship between demographic and job satisfaction level increase with increase of time at work (Ahmed, 1999) which provide logical sense and research says that 
unsatisfied teacher are more like to quit the profession and therefore not to ready and build the future career in teaching. Interesting findings about job satisfaction relation with age except the teachers that are between 40 and 50 (Treamblay, Rondeau \& Lemelin,1998). These teachers perceive low satisfaction in context of promotion prospect. A research of job satisfaction also explained about gender and shows that female employee shows high job satisfaction than male teachers and same observed in teaching profession (Brown \& Hewood, 2005)

\subsection{HR Practices}

There are numerous HR practices than can be effect the employee performance. Taseem \& Soeters (2006) has studied about eight HR practices and their relation with job satisfaction. These HR practices are recruitment and selection practices, placement practices, training practices, compensation practices, employee performance evaluation practices, promotion practices, empowerment and social security or pension. Huselid (1995) studied eleven practices that are personnel selection, performance appraisal, incentive compensation, job design, empower of decision, information sharing, attitude assessment, labor management participation, recruitment efforts, employee training and promotion criteria. Current study explains the relationship between four HR practices that are Compensation Practices, Promotion Practices, Performance Evaluation Practices and Empowerment Practices. In Pakistan per capita income is very low because it is developing country so that these are 4 factors are very important for employee's job satisfactions.

\subsection{Compensation Practices}

Frye (2004) study the relationship among the compensation practices and job satisfaction and examined the positive relationship among them. Previous study show that incentive pay strategies are means to improve the employee overall performance (Ichniowski, 1997). High performance at work has good relation among employee and institutions (Huselid, 1995). Tasema \& Soeters explain that there is a positive relationship among compensation practices and job satisfaction. There is a need to examined the relationship between job satisfaction and compensation practices. After reviewing the above literature it can be expected that there is positive relationship with the satisfaction and there is need to examine in University teacher at Pakistan.

\subsection{Promotion Practices}

Tassema \& Soeters (2006) found that there is a positive relationship among the promotion practices and employee perceived performance. Financially sound organizations like HP (Hewlett-Packard) use the promotion practices to develop their employees (Truss,2001). There is need to examine the relationship among job satisfaction and promotion practice in 
universities. After reading the above literature it can be hypothesized that there is a positive relationship between job satisfaction and promotion practices among universities teachers of Pakistan.

\subsection{Empowerment Practices}

Designation without authority is like establishing much rules but no implementation of those rules..Level of trust of employees increase as they get empowered (Moye \& Henkin, 2006). According to Jarrar \& Zairi (2002) when we give power to employees in decision making that will increase their responsibility in achievement of job and satisfy them. Commitment of employees towards organization is based on empowerment (Lee, Nam, Park \& Lee, 2006) Empowerment is one of HR practices that effect job satisfaction because every employee cannot be motivated with financial incentives. Some people are interested in authority and self actualization and they do not give more importance to the financial benefits but more like self respect. After carefully studying the literature it can be assumed that employee job satisfaction is correlated with job satisfaction in organizations. This relationship need to examine in Pakistan among university's teachers.

\subsection{Performance Evaluation Practices}

Evaluation of employee performance leads to improvement of productivity of organizations and helpful to monitor the performance (Brown \& Hewood, 2005). Productivity and employee performance can be increased through the appraising the employee performance (Brown \& Benson, 2003). Performance appraisal increase the commitment of teacher toward its function (Rahman, 2006). Performance appraisal can be more enhanced by the HRM practices like other human resources practices formal training and financial incentive leads to increase organization's productivity (Brown \& Hewood, 2005). Above literature is enough to develop the assumption that there is positive relationship between performance evaluation practices and job satisfaction and there is need to be examining this relationship among universities teacher in Pakistan.

\section{Theoretical model}

Independent Variables

\begin{tabular}{|l|}
\hline Compensation Practice \\
\hline Promotion Practice \\
\hline Empowerment Practice \\
\hline $\begin{array}{l}\text { Performance Evaluation } \\
\text { Practice }\end{array}$ \\
\hline
\end{tabular}

Dependent Variable

Job Satisfaction 


\section{Methodology}

\subsection{Questionnaire}

The questionnaire of Teseema \& Soerers (2006) is used to develop questionnaire of current study. This questionnaire measures the HR activities that impact on employees satisfaction. Its variables are same as in current research, that's why this questionnaire is selected. Questionnaire of current study is consisting of six sections. First section is regarding to demographics (4 items). Remaining five sections are related to HR Practices like Job satisfaction (5 items), compensation practice (6 items), promotion practice (3 items), empowerment practice (4 items) and performance evaluation practice (6 items).

Teseema \& Soeter (2006) claims that reliability and consistency of questionnaire is tested well in all aspects. Alpha of all sections of questionnaire lay between 0.73 to 0.82 which is acceptable. Liker scale with five points is used to get the response. (point $1=$ strongly disagree, point $5=$ strongly agree)

\subsection{Sampling}

Sixty questionnaires were distributed among full time university teachers of three different sector universities of Pakistan (public, private and semi govt.) response rate was $78 \%$ and 47 questionnaires were get back as a sufficient sample size for analysis. Questionnaires were filled through personal administrations.

\section{Results \& Discussion}

In demographic analysis (Table-1), gender analysis shows that male university teachers re more satisfied with their jobs then female teachers because the mean score of male teacher (3.55) is greater then female teachers (3.38). Dissatisfaction with job in female teachers is not because of discussed HR practices, other factors are there, like work environment and behavior of coworkers. As satisfaction level with HR practices (compensation, promotion, empowerment, performance evaluation) are concern, female teachers are more satisfied then male teachers, as mean score shows (compensation practice (male=2.69 female=3.07), promotion practice $($ male $=2.98$ female $=3.42)$, empowerment practice $\quad($ male $=3.03$ female $=3.25$ ) and performance evaluation proactive ( male $=3.13$ female $=3.38)$ )

Public sector university teachers are more satisfied with their jobs then private and semi government universities, as mean score shows (Public sector $=3.67$ private sector $=3.63$ semi Govt=3.02) because of the more job security in public sector. As satisfaction level with compensation is analyzed, private university teachers are more satisfied then public and semi govt universities teachers. There mean scores are 3.1, 2.84, 2.58 respectively. In consideration of promotion practice, public sector university teachers are more satisfied (3.3) then private (3.25) and semi govt. universities teachers (2.67). Private university teachers are more satisfied with empowerment practice of their universities with mean score of (3.42) then semi govt. (3.08) and public sector universities (3.02). In performance evaluation, public sector university 
teachers are more satisfied with mean score of (3.32). it is because of change in evaluation system from ACR( annual confidential report) to PER( personal evaluation report).

Table-1

\begin{tabular}{|c|l|c|c|c|c|c|}
\cline { 3 - 7 } \multicolumn{2}{l|}{} & \multicolumn{5}{c|}{ Mean Score } \\
\hline $\mathbf{n}$ & Demographics & $\begin{array}{l}\text { Job } \\
\text { Satisfaction }\end{array}$ & $\begin{array}{l}\text { Compensation } \\
\text { Practice }\end{array}$ & $\begin{array}{l}\text { Promotion } \\
\text { Practice }\end{array}$ & $\begin{array}{l}\text { Empowerment } \\
\text { Practice }\end{array}$ & $\begin{array}{l}\text { Performance } \\
\text { Evaluation }\end{array}$ \\
\hline 31 & Male & 3.55 & 2.69 & 2.98 & 3.03 & 3.13 \\
\hline 16 & Female & 3.38 & 3.07 & 3.42 & 3.25 & 3.38 \\
\hline 8 & PVT & 3.63 & 3.1 & 3.25 & 3.42 & 3.21 \\
\hline 27 & Public & 3.67 & 2.84 & 3.3 & 3.02 & 3.32 \\
\hline 12 & Semi Govt. & 3.02 & 2.58 & 2.67 & 3.08 & 2.97 \\
\hline 29 & Less then 3 y & 3.48 & 2.72 & 3.2 & 3.03 & 3.25 \\
\hline 12 & 4---6 y & 3.47 & 3.07 & 3.17 & 3.42 & 3.35 \\
\hline 6 & More then 6 y & 3.63 & 2.81 & 2.72 & 2.85 & 2.78 \\
\hline
\end{tabular}

Table-2

\begin{tabular}{|l|r|r|r|r|r|}
\hline & \multicolumn{1}{|c|}{ JS } & \multicolumn{1}{c|}{ PP } & \multicolumn{1}{c|}{ EP } & \multicolumn{1}{c|}{ PEP } & \multicolumn{1}{c|}{ CP } \\
\hline Job Satisfaction & 1 & $.250^{*}$ & $.295^{*}$ & .228 & $.337^{*}$ \\
\hline Promotion Practice & & 1 & $.405^{* *}$ & $.438^{* *}$ & $.546^{* *}$ \\
\hline Empowerment Practice & & & & $.543^{* *}$ & $.482^{* *}$ \\
\hline Performance Evaluation Practice & & & & & $.504^{*}$ \\
\hline Compensation Practice & & & & & 1 \\
\hline
\end{tabular}

*. Correlation is significant at the 0.05 level.

**. Correlation is significant at the 0.01 level. (JS= Job Satisfaction, $\mathrm{PP}=$ Promotion Practice, EP= Empowerment Practice, $\mathrm{PEP}=$ Performance Evaluation Practice, $\mathrm{CP}=$ Compensation Practice)

As employee experience increase, there level of job satisfaction also increases as result shows. Middle experience teachers (4 to 6 years experience) are more satisfied with compensation, promotion, empowerment and performance evaluation practice.

Relationship between job satisfaction and different HR tools is shown in Table-2.

As literature shows that there is positive relationship between job satisfaction and different $\mathrm{HR}$ practices. Current result shows the same like performance evaluation practice has positive relation with job satisfaction. It is because of the change in appraisal system form Annual Confidential Report (ACR) to Performance Evaluation Report (PER). Current results of the study represent the current level of satisfaction of university teachers with different $\mathrm{HR}$ practices. Compensation practice has most strong relationship with job satisfaction (0.337). It is because of the low per capita income of Pakistan and teachers put compensation at top. It is 
the most influencing HR practice in Pakistan. Empowerment practice also has positive relationship with job satisfaction (0.295) along with promotion practice (0.25). These are supporting the objective of this study. Promotion is representing the more monitory benefits and empowerment give power to employ which give them motivation.

\section{Conclusion}

There are many implications for different sectors of Pakistani universities. First, male teacher of Pakistani universities are not much satisfied with different HR practices (compensation, empowerment, promotion and performance evaluation). Universities administration should have to focus on this side and take proper action towards the improvement of these practices. Teachers of the public sector universities in Pakistan are more satisfied then private and semi govt. universities, that is because of high job security in public sector. High experienced teachers are not much satisfied with HR practices. Institutions should focus on their job satisfaction. Mostly low experience and middle experience teacher are having only masters degree (16 years of education) which is minimum requirement of being university teacher. Many universities have different faculty development programs with the collaboration of Higher Education Commission. More and consistent effort are required for continues improvement.

Positive correlation is there between all HR practices and job satisfaction. Most strong correlation prevails in compensation and job satisfaction. Financial benefits are more important for Pakistani university teachers. Power as motivation and promotion as monitory benefit also works. Universities should take keen interest in enhancement of compensation of their employees. Proper career counseling from university side will improve the performance of teachers and also improve them professionally. 


\section{References}

Ahmed, S. (1999). The emerging measure of effectiveness for human resource management. Journal of Management Development, 18(6), 543-556.

Brown. M. and Benson, J. (2003). Rated to exhaustion? Reaction to performance appraisal processes, Industrial Relation Journal. 34(1), 67-81.

Brown, M., \& Heywood, J. S. (2005). Performance appraisal systems: determinants and change. British Journal of Industrial Relations, 43(4), 659-679.

Frye, M. B. (2004). Equity-based compensation for employees: firm performance and determinants. The Journal of Financial Research, 27(1), 31-54.

Huselid, M. A. (1995). The impact of human resource management practices on turnover, productivity and corporate financial performance. Academy of Management Journal, 38(3), 635-672.

Hodson, R. (1989). Gender Differences in Job Satisfaction: Why Aren't Women More Dissatisfied? The Sociological Quarterly, 30(3), 385-399.

Ichniowski, C., Shaw, K. and Prennushi, G. (1997). The effects of human resource management practices on productivity: a study of steel finishing lines, The American Economic Review, 87(3). 291-313.

Jarrar.y.f., \& Zairi.M. (2002). Employee empowerment-a UK survey of trends and best practices. Managerial auditing journal, 17(5), 266-271.

Lee.Y.K., Nam.F.H., Park.D.H., \& Lee.K.A.(2006). What factors influence customer-oriented prosocial behavior of customer-contact employees?. Journal of Services Marketing,20(4) ,251-264.

Luna-Arocas, R., \& Tang, T. L. (2004). The Love of Money, Satisfaction, and the Protestant Work Ethic: Money Profiles among University Professors in the U.S.A. and Spain. Journal of Business Ethics, 50(4), 329-354.

Michalos, A. C. (1980). Satisfaction and Happiness. Social Indicators Research, 8(4), 385-422.

Mottaz, C. J. (1985). The Relative Importance of Intrinsic and Extrinsic Rewards as Determinants of Work Satisfaction. The Sociological Quarterly, 26(3), 365-385.

Moye.M.J., \& Henkin.A.B.(2006). Exploring associations between employee empowerment and interpersonal trust in managers. Journal of Management Development,25 (2), 101-117.

Rehman. S. A. (2006). Challenges and prospects of HRM in developing countries: testing the HRM-performance link in Eritrean civil service, International Journal of Human Resource Management, 17(1), 86-105.

Schmidt, S. W. (2007). The Relationship between Satisfaction with Workplace Training and Overall Job Satisfaction. Human resource development quarterly, 18(4), 481-498. 


\section{Macrothink

Singhal, S., \& Srivastava, C. (1982). Job Satisfaction-A Needed Reconceptualization. Indian Journal of Industrial Relations, 18(2), 224-207.

Ssesanga, K., \& Garrett, R. M. (2005). Job Satisfaction of University Academics: Perspectives from Uganda. Higher Education, 50(1), 33-56.

Tessema, M., \& Soeters, J. (2006). Challenges and prospects of HRM in developing countries: testing the HRM-performance link in Eritrean civil service. International Journal of Human Resource Management, 17(1), 86-

105.

Tremablay, M., Rondeau, A. and Lemelin, M. (1998). Influence of Human Resource Practices on the Mobilization of Blue-Collar Workers (in french). Proceedings of Meetings of Association Internationale de Psychologie de Langue Française, 97-110.

Truss, C. (2001). Complexities and controversies in linking HRM with organizational outcomes, Journal of Management Studies, 38(8), 1121-1149. 